\title{
HOW IS PARTICIPATORY PLANNING PERCEIVED WITHIN REPRESENTATIVE SYSTEM?: A SWEDISH CASE OF ULLERÅKER REGION
}

\section{TEMSILII SISTEMDE KATILIMCI PLANLAMA NASIL ALGILANMAKTADIR?: İSVEÇ'İN ULLERÅKER BÖLGESİ ÖRNEĞİ}

\author{
Pınar AKARÇAY ${ }^{1}$
}
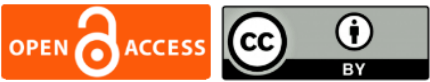

1. Dr. Öğr. Üyesi, Trakya Üniversitesi, Keşan Yusuf Çapraz Uygulamalı Bilimler Yüksekokulu, pinarakarcay@trakya.edu.tr, https://orcid.org/0000-0002-5231-0567

\section{Makale Türü \\ Araştırma Makalesi}

Bașvuru Tarihi

05.04 .2021

Yayına Kabul Tarihi 20.05.2021
DOI

https://doi.org/10.30798/makuiibf.910042
Admission Date 05.20 .2021

Article Type Research Article

Application Date 04.05 .2021 tem

ger

\begin{abstract}
The participatory planning approach that emerged in urban planning in recent years is based on collaborative, communicative, and deliberative planning processes that cover the differences. The main purpose of participatory planning is to include the perspective of actors (political representatives, planners, citizens) in planning processes by developing horizontal planning tools and processes among actors. However, the decision-making system in Sweden is built on representative democracy based on topdown policy-making processes and vertical relations. Therefore, the simultaneous coexistence of representative top-down policy-making processes and multi-faceted participatory arrangements make Sweden an interesting example and suggests that some dilemmas and tensions may arise in practice. At this point, in a political system with strong representative democracy like Sweden, it provides important data on how actors perceive participatory planning and how participatory planning is implemented. In this context, this research discussed how participatory planning is perceived in urban planning in the logic of representative democracy in Sweden. Ulleråker region of Uppsala, in particular, was chosen to carry out the field research, and thus, interviews on the subject were conducted in this region with the main actors of decision-making processes in urban planning such as political representatives, public officials/planners, and citizens.

Keywords: Sweden, Ulleråker Region, Urban Planning, Representative Logic, Logic of Participation.
\end{abstract}

$\ddot{O} \mathbf{z}$

Son yıllarda kent planlamasında ortaya çıkan katılımcı planlama yaklaşımı, farklılıkları kapsayan işbirlikçi, iletişimsel ve müzakereci planlama süreçlerine dayanmaktadır. Katılımcı planlamanın temel amacı, aktörler arasında yatay planlama araçları ve süreçleri geliştirerek, aktörlerin (siyasi temsilciler, planlamacılar, vatandaşlar) bakış açısını planlama süreçlerine dâhil etmektir. Bununla birlikte, İsveç'teki karar alma sistemi, yukarıdan aşağıya politika oluşturma süreçlerine ve dikey ilişkilere dayalı temsili demokrasi üzerine inşa edilmiştir. Bu nedenle, temsili yukarıdan aşağıya politika oluşturma süreçlerinin ve çok yönlü katılımcı düzenlemelerin eşzamanlı olarak bir arada bulunması, İsveç'i ilginç bir örnek haline getirmekte ve uygulamada bazı ikilem ve gerilimlerin ortaya çıkabileceğini önermektedir. Bu noktada, İsveç gibi güçlü temsili demokrasiye sahip bir siyasi sistemde, aktörlerin katılımcı planlamayı nasıl algıladıkları ve katılımcı planlamanın nasıl uygulandığı konusunda önemli veriler sağlamaktadır. $\mathrm{Bu}$ bağlamda, bu araştırma İsveç'te temsili demokrasi mantığında katılımcı planlamanın kent planlamasında nasıl algılandığını tartışmaktadır. Saha araștırması yapmak için, özellikle Uppsala'nın Ulleråker bölgesi seçilmiş ve bu nedenle, anılan bölgede siyasi temsilciler, kamu görevlileri/planlamacilar gibi kent planlamasında karar alma süreçlerinin ana aktörleri ve vatandaşlar ile konuyla ilgili görüşmeler gerçekleştirilmiştir.

Anahtar Kelimeler: İsveç, Ulleråker Bölgesi, Kent Planlaması, Temsili Mantık, Katılimcı Mantı. 


\section{Çalışmanın Amacı}

\section{GENIŞLETILMIŞ ÖZET}

İsveç’te 1991ve 2004 yılında yapılan yerel yönetim yasalarıyla yerel yönetimlere katılımcı karar alma süreçlerini geliştirme görevi verilmiştir. Bu bağlamda belediyelere, aktörler arası iletişim ve diyaloğu özendirecek, aktörlerin bilgi ve farkındalığını arttıracak önlemleri alma görevleri verilmiştir. Benzer biçimde İsveç Planlama Yasası (2006) ile yerel yönetimlere aktörler arası diyaloğu arttıracak katılımcı bir planlama anlayışının geliştirilmesi sorumluluğu verilmiştir. Böylece İsveç’te belediyeler, söz konusuyasalarda yer alan düzenlemeler doğrultusunda, katılımcı planlamayı teşvik eden önlemleri almak zorunda kalmışlardır. Bunlardan biri olan Uppsala Belediyesi, aktörlerin karar alma süreçlerine ve planlamaya katılımını geliştirecek bazı düzenlemeler yapmıştır. Bu bağlamda, Uppsala Belediyesi planlamaya ilişkin kararlarda, karar öncesi diyalog toplantılarına ağırlık veren uygulamalara yönelirken, vatandaşların ve diğer aktörlerin yerel temsilcilerle ve planlamacılarla doğrudan iletişim sağlayabilmelerini kolaylaştıracak araçlar geliştirmiştir. Ancak İsveç’te yerel yönetim sistemi top-down politika yapım süreçlerine ve vertical ilişkiler üzerine kurulmuş temsili demokrasiye dayanmaktadır. Dolayısıyla temsili yukarıdan-aşağıya (top-down) politika yapım süreçleri ve çok yönlü katılımcı düzenlemelerin eş zamanlı birlikteliği İsveç’i ilginç bir örnek haline getirmektedir. Nitekim katılımcı mantık ve temsili mantık, aktörlerin (yerel siyasetçiler, yerel bürokratlar/planlamacılar ve vatandaşlar) rolleri ve karar alma süreçlerine katılımı bakımından birbirleriyle barıştırılamaz derecede mantık farklılıkları içermektedir. Bu bağlamda İsveç’te hem temsili hem de katılımcı pratiklerin birlikteliği temsili ve katılımcı uygulamaların gerilim ve ikilemler yaratabileceğini akla getirmektedir. Bu noktada aktörlerin katılımcılığg nasıl algıladıkları pratikte oluşması muhtemel ikilem ve gerilimlerin anlaşılabilmesine ve bunlara karşılık çözüm mekanizmaları oluşturulmasına yardım edebilir. Ayrıca bu çalışma, katılımcı düzenlemelerin temsili bir sistemde nasıl uygulandığını ya da temsili bir sistemde katılımcı düzenlemelerin kurumsallaştırılmasına yönelik girişimlerin nasıl yapıldığını anlama fırsatı da yaratmaktadır. Bu çalışmada, İsveç’te katılımcı planlamanın karar alma süreci aktörlerince nasıl algılandığı araştırılmıştır.

\section{Araştırma Soruları}

Daha özelde şu sorulara cevap aranmıştır: (1) Yerel siyasal temsilciler katılımcı planlamayı nasıl algılamaktadırlar? (2) Planlamacılar katılımcı planlamayı nasıl algılamaktadırlar? (3) Vatandaşlar katılımcı planlamayı nasıl algılamaktadırlar?

\section{Literatür Araştırması}

İsveç’te katılımcılık tartışmalarının temelinde, özellikle yerel düzeyde vatandaşların siyasi parti politikalarına ve uygulamalarına ilgi ve katılım oranlarının belirgin biçimde düşmüş olması yer almıştır. $\mathrm{Bu}$ sorunun giderilebilmesi maksadiyla, The Swedish Association of Local and Regional Authorities (Sveriges Kommuner och Landsting), yerel düzeyde politika yapım süreçlerine vatandaşların farkındalığı ve katılımını artıracak diyalog önerileri geliştirmiştir. Bu bağlamda, tüm aktörlerin sürekli 
iletişim içinde olduğu, katılımcılara bilgi akışının sağlandığı, katılımcıların temel kaygılarının etkin biçimde dinlendiği ve karara mümkün olduğunca yansıtıldığı diyalog yöntemlerinin önemine dikkat çekilmiştir. Bunun için belediyelere, yerel siyasal temsilciler, vatandaşlar ve kamu görevlileri arasında üç boyutlu bir diyalog ve iş birliği mekanizmalarının oluşturulması önerilmiştir. Böylece belediyelerin rolü vatandaşları etkin biçimde dinlemek, diyalog ve iş birliği araçları geliştirmek iken, vatandaşların rolü, görüş ve kaygılarını yetkililerle paylaşmak ve diyalog süreçlerine katılmak olarak belirtilmiştir. Nihayetinde İsveç'in 290 belediyesinin \%83'ü bu öneriler doğrultusunda yerel diyaloğu geliştirecek çalışmalar yürütmüştür. Belediyeleri katılımcı formda düzenlemeler yapmaya yönlendiren bir diğer etken de, yönetişim olmuştur. İsveç’te yerel düzeyde aktörler arasında network geliştirmeye odaklanmış yönetişim trendi gelişme göstermiştir. Böylece yönetim geleneksel hiyerarşik top-down bir yönetim biçimi olarak görülürken, yönetişim ağ tabanlı yatay (horizontal) bir yönetim formu olarak görülmüştür. $\mathrm{Bu}$ bağlamda belediyelere, diyalog süreçlerini geliştirilmenin yanı sıra organizasyon yapılarını yönetişim doğrultusunda değiştirmeleri de önerilmiştir.

\section{Yöntem}

$\mathrm{Bu}$ çalışmada ana veri toplama yöntemi olarak yarı yapılandırılmış mülakat tekniği kullanılmıştır. Bu yöntemin tercih edilmesinin temel sebebi: (1) Çalışmanın amacı doğrultusunda belirlenen araştırma sorularına anlamlı cevaplar üretilebilmesi (2) Çalışmanın amacı ve problematiği doğrultusunda önceden hazırlanmış sorular dışında, katılımcıların verdikleri cevaplar doğrultusunda katılımcılara farklı sorular da yöneltilebilmesidir. Mülakatlarda yerel temsilcilerin, planlamacı bürokratların ve vatandaşların, diğer deyişle temel karar alma süreci aktörlerinin katılımcı planlamayı nasıl algıladıklarına odaklanılmıştır. Bu bağlamda toplamda 40 kişiyle mülakat yapılmıştır. 3 yerel politikacı, 13 planlamacı ve 24 yerel vatandaşla yüz-yüze mülakatlar yapılmıştır.

\section{Sonuç ve Değerlendirme}

$\mathrm{Bu}$ anlamda, temsili mantığın uzun bir geçmişe dayandığı İsveç’te incelenen Uppsala kenti Ulleråker bölgesi örneği; (1) İsveç’te aktörler arasında farklı katılım algıları olmakla birlikte, aktörlerin planlamaya katılımının, temsiliyet, eşitlik, kamu yararı gibi erdemleriyle temsili demokrasinin ve yine temsili mantığın güçlü biçimde ortaya koyduğu rol, işleyiş ve ilkelere bağlı olduğunu (2) Siyasal temsilcilerin katılımcı planlamanın öneminin farkında olmakla birlikte, temsili demokrasinin kendilerine verdiği vertical ve hiyerarşik rollerin bütünüyle dışında horizontal ve ortaklaşmacı bir katılım algısına sahip olmadıklarını (3) Temsili mantığın meşruiyet unsurlarının temsiliyet, kamu yararı ve eşitlik gibi, siyasal temsilciler tarafindan hassasiyetle üzerinde durulan konular olduğunu göstermektedir. Dolayısıyla Ulleråker örneğinde mülakat yapılan yerel temsilciler, katılımı desteklemekle birlikte, kontrolü kaybedebilecekleri karar alma süreçleri ve temsili mantığa göre demokratik olmayan meşruiyetsiz sonuçlar ortaya koymaktan çekindiklerini ifade eden cevaplar vermişlerdir. Buna göre Ulleråker örneği, aynı zamanda yerel temsilcilerin katılımc1 mantığı ya da aktörler arasında yatay (horizontal) ilişkileri, meşruiyetsiz ve demokratik olmayan sonuçlar 
yaratabilecek süreçler olarak algıladıklarını da göstermektedir. Bu durum horizontal ilişkiler geliştiren katılımc1 süreçlerin, siyasal bir karmaşaya yol açabileceğine yönelik bir tehdit olarak algılandığ sonucunu da vermektedir. Bu nedenle temsili demokrasi içinde mevcut vertical rolleri ve süreçleri muhafaza etme eğilimi gösteren yerel temsilciler, otoriter biçimde gücü paylaşmama arzusundan ziyade, kontrolü ve meşruiyeti kaybetme endişesi taşıdıklarını göstermişlerdir. Bu kaygının altında ise şu üç önemli sebebin yattığ1 tespit edilmiştir; (1) İsveç planlama yasasının, planlama süreçlerinde aktörlerin rolleri ve katılım süreçleri hakkında uygulamayı kolaylaştırabilecek belirgin bir düzenleme ortaya koyamaması ve belediyelerin katılım konusunda bilgi ve deneyim eksikliğidir (2) Güçlü biçimde geleneksel temsili mantığa dayanan planlama ve yerel karar alma süreçlerinin kontrol edilebilir bir nitelik taşımasıdır (3) Yukarıda bahsedildiği gibi İsveç’te yerel yönetimlerin, geleneksel işleyişi tehlikeye atacak gelişmelerden kaçınmasıdır. 


\section{INTRODUCTION}

Participatory planning approach, which is an important city planning theory among policy makers, has gained importance in recent years. With the Local Government Act made in Sweden in 1991 and 2004, local governments were given the task of improving participatory decision-making processes. (For detail, see the Swedish Local Government Act, 2004). In this context, municipalities have been given the tasks to take measures to encourage communication and dialogue among actors and increase the knowledge and awareness of the actors. Similarly, with the Swedish Planning and Building Act (2006), local governments were given the responsibility to develop a participatory planning approach that would increase dialogue among actors (For detail, see Swedish Planning and Building Act, 2006; 2010). Thus, in Sweden, municipalities had to take measures to encourage participatory planning in line with the regulations in these two acts (Listerborn, 2007). Uppsala Municipality, one of these municipalities, has made some arrangements to improve the participation of actors in planning. In this context, Uppsala Municipality has developed mechanisms to make it easier for citizens and other actors to communicate directly with local representatives and planners, focusing on practices of dialogue meetings in planning (For detail, see Uppsala Kommun, www.uppsala.se). In addition, the local government system in Sweden is based on vertical relations among actors and top-down policy-making processes of representative democracy (Castell, 2016). Therefore, the simultaneous coexistence of representative top-down policy-making processes and participatory arrangements make Sweden an interesting case at this point. As a matter of fact, participatory logic and representative logic involve incomparably logical differences among actors (local politicians, local bureaucrats/planners, and citizens) in their roles and participation in decision-making processes. In Sweden, the combination of both representative and participatory practices suggest that representative and participatory practices can create tensions and dilemmas. At this point, the perceptions of actors on participation can help to understand the dilemmas and tensions likely to occur in practice. In this research, how participatory planning in Sweden is perceived by the actors of decision-making process was analyzed. More specifically, answers to the following questions were sought:

(1) How do local political representatives perceive participatory planning?

(2) How do planners perceive participatory planning?

(3) How do citizens perceive participatory planning?

This research focuses more specifically on the Uppsala Municipality and the urban development project prepared for the Ulleråker region of the city of Uppsala. As a matter of fact, Uppsala Municipality is preferred for this research since it is one of the important municipalities in Sweden:

(1) that embeds participatory arrangements to its functioning, 
(2) that make some important participatory arrangements to increase the knowledge, awareness, and active participation of the actors in the decision-making processes.

The reasons for choosing the Ulleråker case are as follows:

(1) Ulleråker is the largest urban development project of the Uppsala Municipality in recent years, with 7000 new buildings (most of which are residential buildings, including shopping, entertainment, sports centers, schools, etc.),

(2) It is a project based on the coordination of many organizations (civil and official), as the Uppsala city in the Ulleråker region has a network of water resources, a health museum, a large green space that citizens use for sports and recreation, and special types of plants and trees,

(3) In the Ulleråker project, direct participation forms were used with the dialogue meetings organized by the municipality for citizens and other participants,

(4) Participation practices in the Ulleråker project are based on representative democracy.

This research is structured as follows: In the first part, the representation of the research and the theoretical background placed on the participatory logic axis are explained. In this context, the basic arguments of representative democracy are discussed through representative logic, while the basic arguments of participatory governance are discussed through participatory logic. Thus, two logicalities incomparably different from the theoretical perspective were compared in terms of representation, power, and role distribution. In the second part, representative and participatory logic in Sweden is discussed. In the third part, the case of Ulleråker is examined. In this context, interviews with local representatives (politicians), planners (bureaucrats) of the Uppsala Municipality, and local citizens living in the Ulleråker region were evaluated and analyzed. This section focuses on how those related actors perceive participatory planning.

In this research, a semi-structured interview technique was used as a data collection method. The main reason for choosing this method is:

(1) To produce meaningful answers to the research questions determined in accordance with the purpose of the research can be better achieved,

(2) Apart from the questions prepared in line with the purpose and problem of the research, different questions can be asked to the participants in line with the answers given by the participants.

The interviews focused on how local representatives, planners/bureaucrats, and citizens; in other words, actors of the main decision-making process perceive participatory planning. In this context, a total of 40 people were interviewed. The interviewees included three politicians, who had attended at least one dialogue meeting regarding the Ulleråker project; 13 planners, who took part in the planning processes of the Ulleråker project and attended the dialogue meetings held for the citizens living in 
Ulleråker, and 24 local citizens, who reside in Ulleråker and attended at least one dialogue meeting. Each interview took an average of 40 minutes and was recorded with an audio recorder.

\section{REPRESENTATIVE LOGIC AND REPRESENTATIVE DEMOCRACY}

Representative democracy is the general name of a political system based on elected representatives who are in the interests of the majority and controlled by the majority. Representative democracy, which tries to preserve the existing order and functioning rather than being innovative and developmental (Held, 2006; Stoker, 2011), is based on the logic of the representative, who is elected to work by-election and who is authorized to act on behalf and account of the citizen (Strom, 2000).

In representative logic, representatives are administrators, and citizens are governed and administered. Participation in regular representative elections in a representative democracy is considered an important tool in maintaining political equality. Indeed, in a well-functioning representative democracy, vertical accountability means and assets are available. Vertical accountability mechanisms operate between the elected representative and the bureaucrat; between the representative and the citizen. Thus, the citizen can follow how political representatives fulfill their duties and promises. The legitimacy of representative democracy is based on political equality, citizen representation, and hierarchical implementations of political decisions on all levels of bureaucrats and public employees (Danielsson et al. 2018). In this context, representative democracy is steered by a political decision-making system with hierarchical and vertical, top-down roles.

It has developed a representative democracy, top-down control, and decision-making system, acting with a network of hierarchical relations and vertical accountability. As a matter of fact, representative democracy is based on the political existence of the representatives, who have come to power by the election, hierarchical practices, and bureaucrats who adhere to it loyally (Danielsson et al. 2018). This requires political representatives and bureaucrats to collaborate for excellent democratic control and an effective problem solution (Hall, 1983; Webber, 1983). Beyond this, while a system of representatives and bureaucrats is determinative and guiding in decision-making processes, it divides the actors into two as insiders and outsiders (Hendriks, 2010). The insiders are political representatives and bureaucrats, and outsiders are other actors. While insiders have the power and responsibility to make decisions, outsiders are limited to expressing opinions on the issues presented to them (Khakee, 2000). Thus, other actors, apart from representatives and bureaucrats, become the party of the views on certain issues addressed to them, shortly consulted, rather than being one of the main actors of the decisionmaking process directly (Monno and Khakee, 2012).

Participatory logic (Patemen 1970; Bachrach 1970; Bacrach and Botwiniek 1992; Barber, 1994; Warren 1992) is mainly based on the advocacy of maximizing participation in public affairs as much as possible. In this manner, participatory logic seeks to promote and intensify citizens' involvement in 
public affairs. In this context, in participatory logic, citizens are regarded as variables of the political process, not external, but internal dimensions, that is, the process of public opinion exchange and the willing process. In this sense, it emphasizes collaborative, communicative, and deliberative decisionmaking processes (Overdevest, 2000).

Table 1. Difference Representative and Participatory Logic

\begin{tabular}{|l|l|l|}
\hline Representation & Representative Logic & Participatory Logic \\
\hline Power distribution & $\begin{array}{l}\text { Representation through political } \\
\text { representatives and (social) interest } \\
\text { groups. } \\
\text { Representatives mediate between } \\
\text { citizens and governing process } \\
\text { (indirect) }\end{array}$ & $\begin{array}{l}\text { Broad part of public (including } \\
\text { nonrepresented, nonactivist, and } \\
\text { nonaligned public). } \\
\text { Direct association between citizens } \\
\text { and governing process. }\end{array}$ \\
\hline $\begin{array}{l}\text { Hierarchical relations. Decision- } \\
\text { making remains the authority of } \\
\text { governors. }\end{array}$ & $\begin{array}{l}\text { Governors as "those with power" } \\
\text { and final decision-makers, } \\
\text { governed as "powerless". }\end{array}$ & $\begin{array}{l}\text { Horizontal relations, decision- } \\
\text { making authority fully shared; no } \\
\text { power. }\end{array}$ \\
\hline Role distribution & $\begin{array}{l}\text { Leaders (governors) as } \\
\text { "guardians": keeping things } \\
\text { together, but as decision-making } \\
\text { actors. Citizens as"consulted } \\
\text { party" }\end{array}$ & $\begin{array}{l}\text { Leaders (goverors) as "coaches": } \\
\text { facilitating and supporting the } \\
\text { process from the sidelines (without } \\
\text { dominating). } \\
\text { Citizens in the leading role, as } \\
\text { "players" in the game. }\end{array}$ \\
\hline
\end{tabular}

Source: (Vandenbussche and Eshuis, 2018)

The participatory logic, which has been participating in urban planning discussions since the 1990s and added the concept of participatory democracy to the understanding of representative democracy, basically included two important issues. The first of these is horizontal power relations between actors, and the second is participatory planning processes that develop negotiations and partnerships between actors. In this context, deliberative, collaborative, and participatory planning approaches such as communicative planning (Healey, 1993; Innes, 1995), argumentative planning (Fischer and Forester, 1993), collaborative planning (Healey, 1997) and deliberative planning (Forester, 1999) have been developed.

The purpose of participatory planning is to develop collaborative participation processes that include deliberative planning processes and differences between actors and to include citizens' perspectives in planning (Healey, 2008). In this context, participatory planning aims to eliminate the inequalities that may occur in terms of different groups in the society by fulfilling the function of protecting the common good.

Participatory planning, who emphasized that representatives (politicians) and planners (bureaucrats) should strive to create partnerships among actors (Fainstein, 2000; Innes, 1998; Healey, 
1997; Davidoff, 1965), advises them to move away from the role and power relations that representative logic imposes on them (Innes, 1995). In fact, in the participatory planning approach, political representatives and planners are seen as the provider of negotiation, cooperation, and partnership among the actors of planning (Forester, 1989; Healey, 1992; Innes 1996). Therefore, representatives and planners were given the responsibility to develop ways to ensure that all actors participate in planning processes (Healey, 1992). Representatives and planners depicted by participatory planning are people who combine their professional knowledge with sophisticated knowledge, participatory value, and communication ability, and in this sense, are somewhat distinct from traditional representative roles, processes, and norms (Healey, 1992). In this context, the planner bureaucrat, similar to the political representative, in participatory planning is an organizer, strategist, and mediator, who tend to share power and authority equally in planning processes, making local government open and attentive to participatory planning.

\section{REPRESENTATIVE LOGIC IN SWEDEN}

Local governments with a long-term self-government understanding in Sweden are based on party-controlled representational democracy in decision-making and implementation processes. However, it should be noted that Sweden has developed a unique model of consensus democracy, whose roots go back to the monarchy in decision-making processes at both the central and local levels (Lijphart, 1999). This model of democracy is based on a consensus-based political system in which all views are represented, and policies are accepted by almost every group of society.

In theory, consensus democracy has two important dimensions. The first is the integrative dimension in decision-making processes, and the second is the indirect dimension in decision-making processes (Hendriks, 2010). While the holistic dimension of consensus democracy means that there are as many groups as possible in decision-making processes; The indirect dimension means that decisionmaking authorities (representatives) maintain their responsibility and power in decision-making processes (Overdevest, 2000). Therefore, it is possible to recount that consensus democracy is based on representational logic (Overdevest, 2000), and thus, representative democracy does not eliminate the vertical, top-down decision-making system.

In consensus democracy, social groups and political representatives play a mediator role between citizens and decision-making processes (Fischer, 1993). Decision making is mainly the responsibility of the representatives. Indeed, representatives are the final decision-makers (Hendriks, 2010). Dialogue processes carried out with different social groups in decision-making processes are consultative. In these processes, representatives perform the function of being an integrative and reconciling guide between different social groups and views (Vandenbussche and Eshuis, 2018). In consensus democracy, as in representative logic, there is cooperation in order to ensure democratic control of representatives and bureaucrats in decision-making processes. In this context, it is likely to 
emphasize that consensus democracy does not directly meet the basic arguments put forward by participatory logic.

\subsection{Swedish Context of Participatory Logic}

Participatory planning discussions in Sweden started in the 1960s; however, effective legal and administrative arrangements in this regard could only be made in the 1990s (Overdevest, 2000). As a matter of fact, through the new planning law known as Planning and Building Act, which was accomplished by Boverket (The Swedish National Board of Housing and Planning) (Boverket, 1998; 2006; 2010) in the 1990s, arrangements, and mechanisms aimed at improvement of communication and dialogue between actors in planning processes were tried to be established. In this context, municipalities have been given the authority to make arrangements to encourage communication and dialogue between actors and increase their knowledge and awareness. However, the responsibility for organizing dialogue meetings covering all actors was also given during the planning processes (Boverket, 2010).

In accordance with the provisions of Chapter 5, 11a and 11b of the Swedish Planning Act (Boverket, 2010), local authorities were held responsible at:

(1) informing everyone who will be affected by the decision about the plan,

(2) preparing inclusive dialogue meetings and their agendas with an understanding that will embrace all participants regardless of who will be affected by the decision or not,

(3) creating an environment, where all participants will be able to express their views openly and freely during the meeting,

(4) keeping all communication channels open,

(5) developing the processes and mechanisms that the participants could be active and effective about the plan.

While this shows that planning authorities in Sweden are affected by participatory planning approaches, it left all the details and authority regarding participatory planning to the municipalities. This created great power and influence for the municipalities in the planning processes (Listerborn, 2007). When looking at the planning processes of the municipalities in Sweden, it is generally as follows: Plans prepared in line with the spatial and technical conditions in the Municipalities Planning and Development Committees are presented to the opinion and contribution of local representatives. Thus, the plans formed by planners and representatives are presented to other actors in line with the Planning and Building Act. After informing, the plans are presented to the consideration of the participants. If necessary, municipalities hold dialogue meetings with citizens and other actors in accordance with the Planning and Building Act regulations. In these dialogue meetings, face-to-face interviews are done with the participants, their opinions about the plan are received, and their questions 
are answered. Local representatives decide when the dialogue process will start and when it will end. After the dialogue meetings are ended, the city council negotiates and accepts the plan and sends it to the City Council for approval.

All these steps taken towards participation in Sweden have caused some controversy. Especially at the focus of these discussions, which emerged from the perspective of democracy, problems such as deterioration of political equality, limitation of accountability, lack of representation of all groups, loss of legitimacy of representative democracy had aroused (Hedlund and Montin, 2009). This has led to the introduction of participatory arrangements in representative logic and the development of a model that puts citizen participation in consultation processes (Castell, 2016). One of the reasons is that political representatives in Sweden accepted that actors' participation in planning is important, but they have a narrow and restrictive attitude in practice (Vestbro, 2012).

However, some authors, who linked the outcome to the system of local governments' representation in Sweden stated that municipalities do not favor radical changes that would jeopardize representative democracy and representative decision-making processes (Castell, 2016; Tahvilzadeh, 2015; Monno and Khakee, 2012). Thus, while local governments have a positive approach to the participation of all actors in planning, they have tried to combine participation with representative democracy with a long tradition and control power (Castell, 2016). Eventually, this approach had limited the development of horizontal and collaborative planning processes, where political representatives and planners guide all actors to participate in direct planning.

\subsection{Ulleråker City Development Plan: Case Description}

Ulleråker is a region located in the south of Uppsala, Sweden's fourth-largest city. In Ulleråker, located $2.5 \mathrm{~km}$ from the Uppsala city center, there are approximately 1,800 residents that mostly comprise of Swedes, who have an almost high level of education, and are of the middle-upper income group. As one of the most popular areas to reside in Uppsala due to its unique nature and proximity to the city, Ulleråker region has been included in the city development program of the Uppsala Municipality. Within the scope of this program, a comprehensive plan has been prepared, including a total of 7,000 new structures, a majority of which will be residential in addition to shopping centers, schools, kindergartens, sports centers, indoor and outdoor parking areas as well as other social life centers. The program, which is expected to be completed by 2030, will provide accommodation to 20,000 people in the Ulleråker region. In this vein, the importance of the Ulleråker case is that, firstly, it is a comprehensive plan, the largest created in recent years, and will change the structure and nature of Ulleråker region, and secondly, its result will affect not only Ulleråker region but also the whole of Uppsala city.

During the Ulleråker planning process, the Uppsala Municipality held a total of 6 dialogue meetings with citizens living in the region. The purpose of these dialogue meetings was to inform the 
citizens about the intended plan, answer their questions, get their opinions regarding the plan, and make final arrangements to the plan accordingly. In this context, the first meeting was held in January 2015. Approximately 100 people attended the dialogue meetings held by the municipality (Uppsala Kommun, 2016). The majority of the participants reside in Ulleråker. The meeting was attended by the municipality's plan and project managers, environmental coordinator, experts working in the relevant departments of the municipality, experts working in the fields of transportation, education, planning, culture and sports, some local political representatives, the construction company undertaking the project, architects and Link Consultancy Company (For detail, see Uppsala Kommun, 2016). The municipality received assistance from Link Consultancy Company to develop a more effective dialogue with the participants. Thus, during the dialogue process, the municipality organized a workshop by dividing the participants into 14 groups of 10 people. A few officials from Uppsala Municipality took part in each group (Uppsala Kommun, 2016).

The second dialogue meeting was held in April 2016. In this meeting, it was discussed what changes could be made in the plan to reduce participants' concern. The third and fourth dialogue meetings were held in May and June 2016. At these meetings, discussions on plan change continued (For detail, see Uppsala Municipality, 2016). The fifth dialogue meeting was held in August 2016. At this meeting, some minor changes were made to the Ulleråker plan. In this context, 4 of the 10 blocks with 12 floors have been reduced to 8 floors, and the connection lines of 2 highways have been changed in order to reduce the traffic density. After the last dialogue meeting was held in December 2017, the Ulleråker plan was accepted by the Uppsala Municipality. Figure 1 shows the Ulleråker plan (graycolored and pink partitioned sections show the new structures to be built) accepted by the Uppsala Municipality. 
Figure 1. Ulleråker Plan

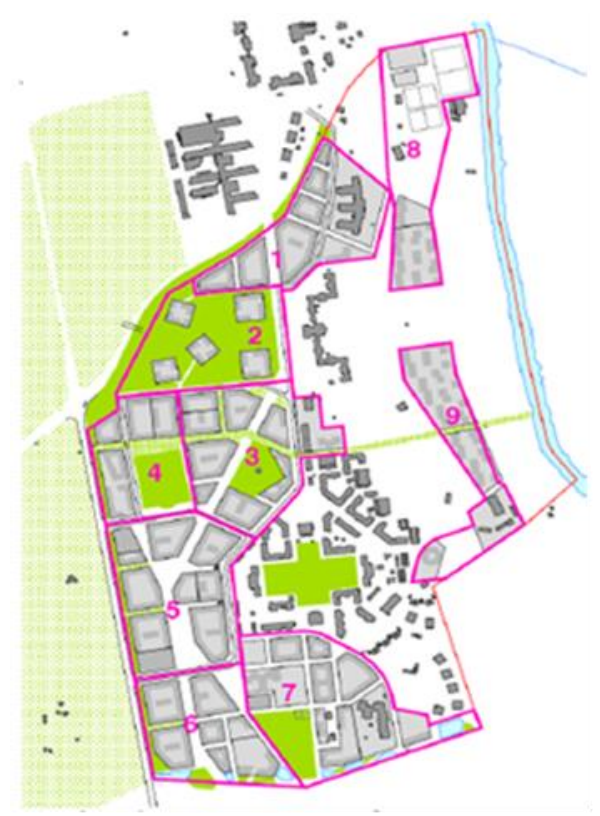

Source: (Uppsala Municipality, 2016)

Figure 2. Ulleråker Map

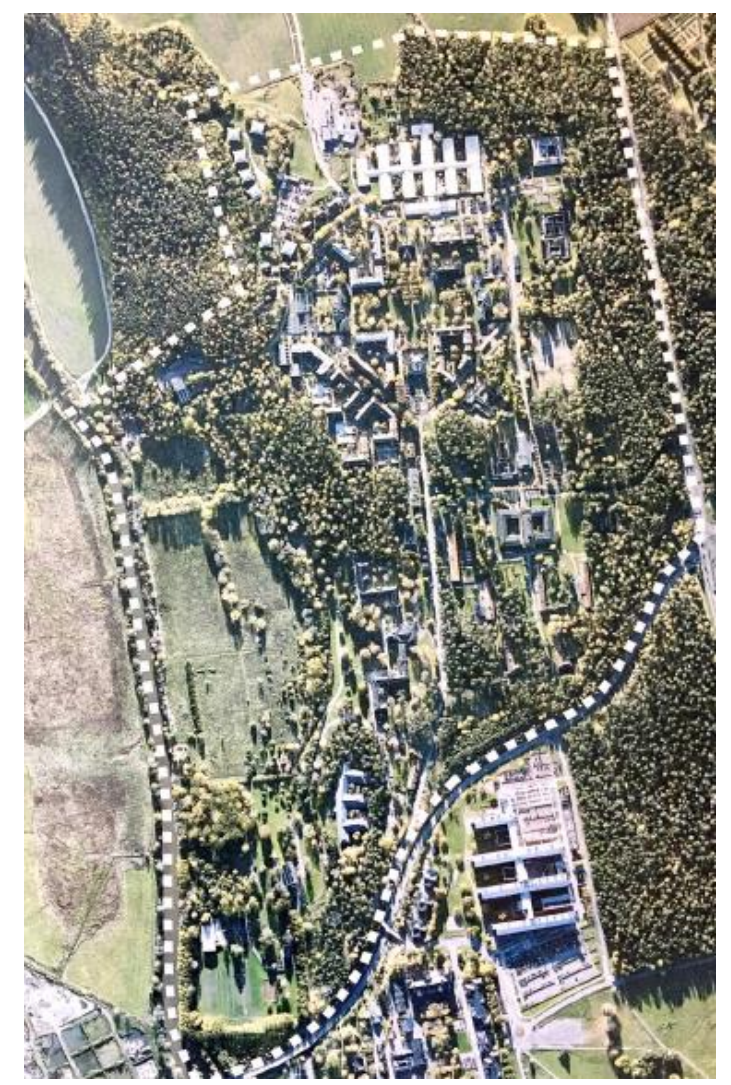

Source: (Uppsala Municipality, 2016) 


\subsection{Analysis of the Ulleråker Case}

In this section, the results of the interviews conducted with the main actors of the planning process, such as local politicians, planners, and local citizens, are given. In this context, findings were explored from the answers the participants gave to the research questions presented below.

\subsubsection{How do the local politicians of the Uppsala Municipality perceive participatory} planning regarding the Ulleråker project?

Local representatives interviewed in the case of Ulleråker accepted that participatory planning should be developed in order to establish more democratic plans, but they gave answers indicating that they perceive participatory planning as an element that completes representative decision making processes democratically. According to them, representative democracy is a political system where elected representatives make the most conceivable decision that fits the interests of the majority, as represented in representative logic. However, this does not mean that only elected representatives make the decision. Indeed, representative democracy has vertical accountability mechanisms that other actors can use. However, the main consideration, according to the local representatives interviewed, is to develop a participatory path without breaking away from the legitimacy ground of representative democracy. Otherwise, serious democratical legitimacy problems may arise. In this context, participatory planning is expressed as the stretching of representative democracy in a way that does not cause legitimacy problems to representative democracy. Thus, the perception of participation that has not been separated from the legitimacy ground of representative democracy has been revealed.

However, it should be noted that the perception of political representatives clearly depicts that elected people are more concerned about losing control and legitimacy rather than wishing to share power in an authoritative manner. As a matter of fact, while the legitimacy of representative logic is based on the presence of representatives who have come to power by-election, the hierarchical relations network and vertical top-down political decision-making system, the legitimacy ground of participatory logic is based on collaborative, horizontal decision-making processes and the ability of citizens to be one of the actors of decision-making processes without the need for a representative. These two logics, which is quite different from each other, create tensions and dilemmas, as can be seen in the responses of the representatives. Ultimately, this pushes representatives to be protective and conservative against any threat that would endanger the legitimacy of representative democracy. As a matter of fact, the representatives interviewed gave answers in this direction.

"We are political representatives who come to work with democratic elections and serve on behalf of citizens; this means fulfilling the roles and responsibilities of representative democracy given to us, without excluding citizens' views and demands... While the views of citizens on all issues, including planning, guide us, we have to take the necessary measures to avoid exposing the current political system to democratic problems (...) Because it is the primary duty of both public officials and us to keep representative decision processes effectively and democratically under control (...)" 
The perception of participation of the interviewed representatives is to stretch representative decision-making processes to develop a dialogue with other actors. However, it should be underlined that the stretching mentioned here includes consultation activities such as informing and getting the opinions of the actors rather than the cooperation or partnership between the actors mentioned by the participatory logic. Therefore, the participatory logic and participatory planning approaches mentioned above do not correspond exactly to the basic arguments. In this context, the perception of participation expressed by the interviewed representatives does not imply that citizens and other actors can be directly involved (without the need of a representative) as one of the main actors of decision-making processes, as suggested in participatory logic and participatory planning approaches. Thus, the perception put forward by the representatives is not a perception of participation, where the power and authority are shared equally, as the participatory logic has mentioned, that nobody has the privilege to be a guiding and determining authority, and therefore the outcomes and responsibility of the decision-making process are shared equally among the actors. For this reason, the perception of participation put forward by the representatives is not directly based on a collaborative and participatory planning and decision-making model.

"Our participatory practices are dialogue and consultation activities that include informing actors and getting their thoughts and suggestions (...) It is very important for us to see participants attending these meetings and expressing their opinions (...) However, this does not mean that we will definitely decide in the direction they want (...) Because there are equality, general public interest, and other political priorities that we must observe in the representative democracy (...)"

Participatory planning perception revealed by the interviewed representatives, it was limited to informing and getting opinions of the participants about the plan rather than incorporating the perspective of the actors in the planning processes, developing partnership and collaborative participation processes that include horizontal participatory processes and differences between the actors, as included in the literature. Thus, we can conclude that, as the participatory planning approaches demonstrate, the perception of planning that actors can actively participate in and influence in the planning processes has not been sufficiently developed yet.

"I think there is a wrong conceptualization in participatory planning (...) Others base the participatory planning on the processes developing in the partnership and direction of all actors, ignoring representative democracy; however, there is still a representative democracy that works effectively (...) Accordingly, it is very clear that decision-makers are representatives (...) We consider the opinions coming from them in terms of their applicability in a way not to cause legitimacy problems in the representative system (...)"

In addition, the interviewed representatives gave answers indicating that they perceived participatory planning as the process in which legal regulations were followed, in accordance with the provisions of the Local Government Act and the Swedish Planning and Building Act, as stated in the previous pages. Accordingly, they overlapped the implementation of legal arrangements, such as 
informing everyone who will be affected by the decision about the plan, holding dialogue meetings to include everyone who wants to participate, creating an environment where all participants can express their views freely, and keeping all communication channels open.

"The participation of citizens and other actors in planning is regulated by our laws. It is our other duty to fulfill the regulations and processes specified in other relevant laws, such as planning law. For this reason, we organize dialogue meetings with the participants, as stated in these laws (...) In these meetings, we explain the plan to the participants and get their opinions (...) Meetings held are consultative (...) We evaluate and decide together with our planner whether the opinions received can be reflected in the plan or how many of them can be reflected (...)"

\subsubsection{How do planners of the Uppsala Municipality who have worked on the Ulleråker} planning project perceive participatory planning?

Planners interviewed on the case of Ulleråker have agreed that participatory planning is necessary to produce more effective and democratic plans, but have revealed different perceptions of participatory planning. One of the reasons for this can be considered to be the difference between representative logic and the planner/bureaucrat role and definitions put forward by participatory logic. The planner put forward by representative democracy is a bureaucrat kneaded with bureaucratic values and professional expertise, integrated with hierarchical procedures, norms, representative politics, and institutions. However, the planner put forward by participatory planning is a figure responsible for developing negotiations, cooperation, and partnership among the actors in the planning processes based on equal power relations. While these two diametrically opposite definitions cause dilemmas and tensions in practice, they may lead to differences in the perceptions of the planners.

Interviews were conducted with a total of 13 planners. The answers given by the planners interviewed revealed that there were 3 different participatory planning perceptions in general:

(1) The first is similar to the definition of participatory planning in the literature. In this context, 4 of the planners interviewed stated that they perceive participatory planning as negotiator, deliberative and collaborative processes that develop horizontal participatory relations and no one is a direct decision-making power and authority,

(2) The second perception of participation is based on the representative logic and functioning, roles, and processes of representative democracy. In this context, 5 planners interviewed gave answers indicating that they perceive participatory planning as processes that democratically complement existing planning processes based on representative decision-making processes,

(3) The third is the perception of processes in which existing policies and plans are tested, and legal procedures are carried out in the axis of representative logic and representative democracy. In this context, 4 planners interviewed gave answers indicating that they have this perception. By these perceptions, the answers given by the planners are analyzed in the following paragraphs. 
The 4 planners interviewed stated that planning processes - as discussed in the participatory planning literature - should be based on diversity, coordination, integration, and deliberation. In this context, they expressed that they perceive participatory planning as processes that enable actors to participate in planning and enable them to directly influence on planning beyond their participation in a simple and formal manner. In this sense, they based their perceptions of participatory planning on the development of collaborative and communicative planning processes involving horizontal deliberative processes and differences between the actors and including the perspective of the participants in the planning processes, as indicated by the participatory logic, according to them, planners and local politicians should work in cooperation to develop this participatory perception. However, they stated that in Sweden, the concerns of planners and representatives about losing control in democratic legitimacy and planning processes prevented the development of participatory planning processes as they perceive.

"Participatory planning means horizontal relationships between actors and deliberative processes beyond the hierarchical processes (...) For this, both (us) planners and politicians should be more courageous (...) We cannot achieve this with a constant concern for democratic legitimacy or fear of losing control (...)"

In this context, the planners interviewed emphasized that the representatives and planners should strive to create consensus among the actors. Therefore, they stated that planning processes should have meaning beyond informing and consulting the participants. In this sense, they stated that, as in the case of Ulleråker, it was inadequate that participation in planning included only information and consultation processes.

"What did we do during the Ulleråker planning process? We informed the participants about our plan and answered their questions (...) So we did not plan together (...) We did not ask them what kind of plan makes you happy or how to plan your region (...) We explained the plan we made and answered questions about this plan (...) When there was more than expected reaction to the plan, we made two optional plan drafts by making minor changes in our plan, that's all that we did (...)"

On the other hand, the 5 planners interviewed gave answers showing that they perceived participatory planning as a factor that complemented the existing planning processes based on representative decision-making processes. For this reason, the information and consultation of the participants are seen as the stages that complete the planning process democratically. This perception is aimed at maintaining the understanding that decision making is mainly the responsibility of the representatives, and on the other hand, planning is the responsibility of the planners, as described by the representative logic. As a matter of fact, as revealed by the representative logic, while the decisionmaking processes are based on a system in which representatives and bureaucrats are decisive and guiding, it continues to position the actors as insider and outsider. Therefore, while those who are inside are political representatives and planners, those who are from outside maintain their perception. While 
it considers insiders having the power and responsibility to make decisions, it limits the outsiders to express their opinions on the issues presented to them.

"Since planning is a business that requires knowledge and expertise, it is inevitable for representatives and planners with this knowledge and expertise to act together (...) However, this is not a process that excludes citizens (...) Because, as in Ulleråker's planning process, we inform them about the plan, answer their questions and get their opinions (...) This makes the planning process more functional and democratic. However, we should remember that we cannot reflect everything that citizens who do not have sufficient knowledge and expertise to say (...)"

The 4 planners interviewed gave responses stating that they perceive participatory planning as a strategic method in which existing policies and ideas are tested and formal and procedural processes in which legal norms are followed. In this context, the planners maintain formal representative processes rather than improving collaborative and communicative participatory planning perception among actors based on horizontal deliberative processes as in the literature. Therefore, their perception is to carry out legal procedures without disrupting the role and power relations of representative democracy.

"We inform the participants about a pre-prepared plan as stated in the law, answer any questions and get positive/negative opinions about the plan (...) In the case of Ulleråker, we did the same procedures (...) Our most important task in planning and decision processes is to fulfill legal regulations (...) Thus, we both applied the laws and saw what the participants liked or did not like in the plan we prepared (...)"

\subsubsection{How do local citizens perceive participatory planning regarding the Ulleråker} project?

In the case of Ulleråker, it is seen that the interviewed citizens have different perceptions of participatory planning. Almost completely opposite perceptions have been observed. The first of the clearly observed perceptions is the perception of participation, which supports representative roles, processes, and decision-making, and recognizes that the influence of citizens are/should be limited in planning processes. The second is the perception of participation, which, while being aware of the existing representative roles, processes, and decision-making logic, does not recognize that the influence of citizens are/should be limited in planning processes. In this section, 24 participants were interviewed. In general, 6 people interviewed are in the first group, and the remaining 18 people are in the second group.

The first group, mostly composed of people in the middle-age and middle-income groups, gave answers indicating that they perceived participatory planning as informing and consulting citizens in line with the legal regulations in the planning process of the municipality. This perception is based on a political system with hierarchical and vertical roles in the implementation of the concepts that ensure the legitimacy of representative democracy, as well as the need to act together with the elected representatives and bureaucrats responsible for running this system. For this reason, the participants in the first group distinguished the participants' perceptions of planning, those with the power to make 
decisions (i.e., from the inside) and those with the responsibility to express opinions (i.e., from outside). Therefore, they have demonstrated a perception of participation, where decision-making authorities maintain their responsibility and power in the planning processes and fulfill their role as a conciliator among other actors through information and consultation processes.

"We are not representatives or planners, so we don't dominate the issue as much as politicians and planners (...) Therefore, giving the roles of representatives or planners to citizens can have wrong results both democratically and technically (...)"

The second group of citizens gave answers showing that they perceive participatory planning as horizontal processes that develop cooperation and partnership between actors, as in the literature. Accordingly, participants' perceptions of participatory planning, as in participatory planning approaches, are based on some factors perceived that planning should:

(1) include differences and based on non-hierarchical processes,

(2) base on the interaction between actors,

(3) develop horizontal relationships between actors,

(4) rely on tools and processes through which they can steer and influence planning, beyond the simple and formal engagement of citizens.

Therefore, they have put forth a sort of participatory planning perception, in which the influence of citizens is not limited to express their opinions and is not based on representative logic. For this reason, they stated that solely consultation and giving the information could not develop robust participatory planning. They gave answers indicating that they had a participation perception in the planning processes far beyond the traditional roles, in which local politicians and planners are determinant. According to them, politicians and planners should take a position to develop negotiation and partnership relations among actors, and thus share the responsibility of planning.

"The meetings of the municipality mostly focus on answering our questions and getting our opinions (...) They take note of the opinions they receive from us; however, I don't think these views work very well in shaping the plan (...) Because in other meetings, debates are conducted on similar plan drafts (...) It is more meaningful to develop methods and tools that we can penetrate into the plan instead of simply consulting (...)"

\section{CONCLUSION}

Representative decision-making processes founded on the logic of representative democracy are surely based on the fact that the political representatives come to power through the elections, and thus have the power to make decisions on behalf of the citizens and the bureaucrats, who stick to the democratic principles of the representative system; in this line, the political representatives are the key authority in the decision-making and steering processes. Therefore, decision-making processes in representative democracies are carried out in cooperation and control of the representatives and 
bureaucrats. By this view, the representative democracy set on the roles of the vertical, top-down hierarchical relations among the actors in the decision-making processes, have a different understanding that cannot be matched with participatory logic.

On the contrary, the participatory logic, which advocates the development of decision-making processes through horizontal and collective relationships among the relevant actors, lines up with a logic of participation justified an equal distribution of power among the actors, in which everyone may have the equal capacity to influence decision-making processes. In this sense, the role of political representatives and bureaucrats in the participatory logic is to produce participation tools and mechanisms that would encourage and increase the participation of all actors in decision-making processes by developing deliberative and collaborative processes.

Participatory logic, which addresses the direct and effective participation of all actors in the decision making processes, paved the way for the development of participatory planning approaches in the field of urban planning. Therefore, in the decision-making processes regarding planning, participatory planning approaches mostly rely on the participation of large-scale actors in the horizontal direction rather than vertical, hierarchical participation processes for planning dictated by representative logic. However, participatory logic, which, in practice, strives for a robust place in a representative democracy, has not yet developed a clear tool of established roles and means among actors regarding participation in planning. Therefore, it should attentively be noted that the realization of participatory logic is firmly related to how it is perceived by actors.

In this context, the case of Ulleråker of Sweden, where representative logic is founded on a long past, is analyzed in this research and showed us the following findings:

(1) Firstly, although there are different perceptions of participation among actors in Sweden, the participation of actors in planning is strongly dependent on the role, functioning, and principles of representative democracy and representative logic with its virtues such as representation, equality, and public interest,

(2) Second, while political representatives are aware of the importance of participatory planning, they do not have a horizontal and collective perception of participation outside of the vertical and hierarchical roles that representative democracy has given them,

(3) Third, the legitimacy elements of representative logic, such as representation, public interest, and equality, are the issues that are delicately and attentively emphasized by political representatives.

Local representatives interviewed in the case of Ulleråker gave answers stating that, while supporting the participation of all actors, they were reluctant to bring out undemocratic and illegitimate results regarding representative logic, and thus, decision-making processes where they could lose control. Accordingly, the case of Ulleråker shows that local representatives perceive participatory logic 
and horizontal relations among actors as processes that can surely produce illegitimate and nondemocratic results. This clearly concludes that participatory processes that develop horizontal relationships are perceived as a threat to the political system as well. Therefore, local representatives, who tended to retain existing vertical roles and processes dictated by representative democracy, put forward by perceptions that they were concerned about losing control and legitimacy rather than not wishing to share power and authority. It is analyzed those three significant reasons lie behind this concern:

(1) The Swedish planning law is unable to provide a clear regulation on the roles of actors and participation processes in planning processes, and the lack of knowledge and experience of municipalities in participation,

(2) Planning and local decision-making processes that strongly based on traditional representative logic are controllable,

(3) Local governments in Sweden, as mentioned above, refrain from developments that would endanger representative democracy.

Thus, the case of Ulleråker clearly put forth those local representatives perceive the participation of actors in planning as processes that are not completely separate from representative democracy; on the contrary, complements representative democracy. In this context, the participation of actors in planning is built on the perception of performing legal processes that are not completely torn off from the logic of representation, rather than horizontal participatory processes where power relations are equally distributed, and responsibilities are shared equally.

On the other hand, the case of Ulleråker has shown that planners perceive participatory planning in almost the same direction as political representatives.

In this sense, the interviewed planners underlined that participatory planning is necessary and crucial for developing better and democratic plans. However, they used expressions to show that they perceive participatory planning as a strategic method, in which existing ideas are tested and a formal process in which legal norms are fulfilled. Therefore, in the case of Ulleråker, planners have indicated that they perceive participation in planning as performing strategic and formal processes rather than developing horizontal participatory planning processes among actors. In this context, the Ulleråker case evidently demonstrated that the main priority of the planners was to carry out the legal processes. Although the fulfillment of legal obligations was a priority, the planners interviewed have also accepted that planning and decision-making processes based on representative logic do not allow effective participation.

In the case of Ulleråker, while local citizens recognize that in planning and decision-making processes dominated by representative logic, their impact on planning is limited, it is divided into two 
as those who perceive participation within the limits of representative democracy and those who perceive it as more horizontal, collaborative and participatory processes. This shows that citizens' perception of participatory planning is formed in two different directions. As a matter of fact, those who perceive the participation of citizens in planning, in the axis of traditional planning processes dominated by representative logic, stated that planning should be under the control and direction of the planners and political representatives since it requires knowledge and expertise. Therefore, these citizens, who had not more participatory demands in the planning process, did not oppose to the planning processes, in which traditional roles were maintained, even though these citizens did not support the Ulleråker project as it would greatly change the region they live in and concentrate it with many new structures.

On the other hand, other citizens, who opposed traditional roles and planning processes, advocated for the planning processes to be based on deliberative, collaborative and participatory horizontal processes, while accepting the existence of representative logic. While this group of citizens made their discourses mostly on participatory democracy and participatory planning approaches, they criticized the decision making processes indexed to the representative logic. By these views, the following issues have been effective in shaping the participatory planning perceptions of that group of citizens:

(1) The fact that the municipalities have made arrangements to increase awareness about citizens' participation in planning in line with the regulations of planning or local administration has increased the expectations of citizens to penetrate into the planning processes,

(2) Participatory approaches or theories that emerged in the field of planning, as in many different fields, had led to the perception of collaborative and participatory planning. This fully supported the development of the perception that the impact of citizens on planning processes should be far beyond the information and consultation processes.

Last but not least, it will wisely be appropriate to emphasize the following finding as to the final words. The perceptions of the main political and public actors about participatory planning directly shape the planning processes. In this sense, the political representatives' and public officials/planners' approaches that emphasize representatives roles and principles of representative democracy reveals the effort that places participatory planning into a representative system. This situation leads to a limited perception of participatory planning and the limited impact of non-official actors in the planning.

\section{REFERENCES}

Barber, B. (1984). Strong democracy, participatory politics for a new age. Berkeley, CA: Berkeley University of California.

Boverket (1998). Vem bestämmer? Om medborgarinflytande och kommunal planering (who is in charge? About citizens' influence and municipal planning). Karlskrona: Boverket. 
Castell, P. (2016). Institutional framing of citizen initiatives: A challenge for advancing public participation in Sweden. International Planning Studies, 21(4), 305-316.

Danielsson, M., Hertting, N., and Klijn, E.H. (2018). Tricky for good reasons: Institutionalizing local participatory governance in representative democracy. N. Hertting and C. Kugelberg (Ed.). Local participatory governance in representative democracy in (1863). New York and London: Routledge.

Davidoff, P. (1965). Advocacy and pluralism in planning. Journal of the American Institute of Planners, 31(4), 331-338.

Fainstein, S. S. (2000). New directions in planning theory. Urban Affairs Review, 35(4), 451478.

Fischer, F. (1993). Citizen participation and the democratization of policy expertise: From theoretical inquiry to practical cases. Policy Sciences, 26(3), 165-187.

Forester, J. (1989). Planning in the face of power. Berkeley, CA: University of California Press.

Forester, J. (1999). The deliberative practitioner: Encouraging participatory planning processes. Cambridge, MA: MIT Press.

Habermas, J. (1984). The theory of communicative action. London: Polity Press.

Hall, P. (1983). The Anglo-American connection: Rival rationalities in planning theory and practice, 1955-1980. Environment and Planning B, Planning and Design 10, 41-46.

Healey, P. (1992). A Planner's day: Knowledge and action in communicative practice. Journal of the American Planning Association, 58(1), 9-20.

Healey, P. (1993). The communicative work of development plans. Environment and Planning $B, 20,83-104$.

Healey, P. (1997). Collaborative planning: Shaping places in fragmented societies. London: Macmillan.

Healey, P. (Ed.) (2008). Interface: Civic engagement, spatial planning and democracy as a way of life. Planning Theory \& Practice, 9, 379-414.

Hedlund, G., and Montin, S. (Ed.) (2009). Governance på svenska. Stockholm: Santérus Academic Press Sweden.

Held, D. (2006). Models of democracy. Cambridge: Polity Press.

Hendriks, F. (2010). Vital democracy: A theory of democracy in action. New York: Oxford University Press Inc.

Innes, J. E. (1995). Planning theory's emerging paradigm: Communicative action and interactive practice. Journal of Planning Education and Research, 14, 183-191.

Innes, J. E. (1996). Planning through consensus-building: A new view of the comprehensive planning ideal. Journal of the American Planning Association, 62(4), 460-472.

Innes, J. E. (1998). Information in communicative planning. Journal of the American Planning Association, 64(1), 52-63.

Khakee, A. (2000). Samhällsplanering. Nya mål, perspektiv och förutsättningar (Planning, New Goals, Perspectives and Premises). Lund: Studentlitteratur.

Lijphart, A. (1999). Patterns of democracy: Government forms and performances in thirty-six countries. New Haven, CT: Yale University Press.

Listerborn, C. (2007). Who speaks? And who listens? The relationship between planners and women's participation in local planning in a multi-cultural urban environment. GeoJournal, 70(1), 61-74. 
Monno, V., and Khakee, A. (2012). Tokenism or political activism? Some reflections on participatory planning. International Planning Studies, 17(1), 85-101.

Moote, M. A., McClaran, M. P., and Chickering, D. K. (1997). Theory in practice: Applying participatory democracy theory to public land planning. Environmental Management, 21(6), 877-889.

Overdevest, C. (2000). Insights and applications. Participatory democracy, representative democracy and the nature of diffuse and concentrated interests: A case study of public involvement on a national forest district. Society and Natural Resources, 13(7), 685696.

Pateman, C. (1970). Participation and democratic theory. London: Cambridge University Press.

Stoker, G. (2011). Building a new politics: A report prepared for the British Academy. London: British Academy.

Strom, K. (2000). Delegation and accountability in parliamentary democracies. European Journal of Political Research, 37(3), 261-290.

Tahvilzadeh, N. (2015). Understanding participatory governanvce arrangements in urban politics: Idealist and cynical perspectives on the politics of citizen dialogues in Goteborg, Sweden. Urban Research \& Practice, 8(2), 238-254.

Uppsala kommun (2016). Ulleråker medborgardialog, Stadsbyggnadsförvaltningen. Uppsala.

Uppsala Municipality (Uppsala Kommun) (2016). Ulleråker medborgardialog, Rapport: Möte om detaljplan för Vattentornsparken. Uppsala, Sverige: Uppsala Kommun.

Vandenbussche, L., and Eshuis, J. (2018). A Trojan Horse in the representative system: participatory governance in Rotterdam and the redevelopment of the Fenix Storehouses. N. Hertting and C. Kugelberg (Ed.). Local participatory governance in representative democracy in (18-63). New York and London: Routledge.

Warren, M. (1992). Democratic Theory and self-transformation. American Political Sciences Review, 86, 8-23.

Webber, M. M. (1983). The myth of rationality: Development planning reconsidered. Environment and Planning B, Planning and Design, 10, 89-99.

Vestbro, D. U. (2012). Citizen participation or representative democracy? The case of Stockholm, Sweden. Journal of Architectural and Planning Research, 29(1), 5-17. 